\title{
Evolving concepts in the selection of immunosuppression regimen for liver transplant recipients
}

This article was published in the following Dove Press journal:

Hepatic Medicine: Evidence and Research

I2 May 201 I

Number of times this article has been viewed

\author{
Jayme E Locke \\ Andrew L Singer \\ Johns Hopkins Medical Institutions, \\ Department of Surgery, Division of \\ Transplantation, Baltimore, MD, USA
}

Correspondence: Andrew L Singer 720 Rutland Avenue, Ross 765,

Baltimore, MD 21 205, USA

$\mathrm{Tel}+\mathrm{I} 4106148297$

$\mathrm{Fax}+\mathrm{I} 4106147649$

Email asinger I@jhmi.edu

\begin{abstract}
The introduction of calcineurin inhibitor (CNI) based immunosuppression has revolutionized the field of liver transplantation by dramatically reducing the incidence of acute cellular rejection and prolonging patient and allograft survival. However, the introduction of CNIs has also come at the price of increased patient morbidity, particularly with regard to the well-known nephrotoxic effects of the medications. In an effort to minimize the adverse effects, immunosuppression regimen have evolved to include the use of various induction agents and purine synthesis inhibitors to limit the dose of CNI necessary to achieve low acute cellular rejection rates. Careful assessments of risks and benefits are needed as these newer agents have their own side effect profiles. In addition, the impact of newer immunosuppression regimen on hepatitis $\mathrm{C}(\mathrm{HCV})$ recurrence has not been completely elucidated. This review will provide an overview of the most common immunosuppression regimen used in liver transplantation and discuss their impact on acute cellular rejection, patient and allograft survival, and HCV recurrence.
\end{abstract}

Keywords: liver transplantation, immunosuppression, acute cellular rejection, patient and graft survival, hepatitis $\mathrm{C}$ recurrence

\section{Introduction}

A new era in liver transplantation began in the early 1980s heralded by the introduction of cyclosporine (CsA), a powerful immunosuppressant that in combination with corticosteroids was capable of reducing the incidence of acute rejection. ${ }^{1}$ The ability to dramatically reduce the incidence of acute rejection among liver transplant recipients, and therefore reduce mortality, paved the way for a 1983 National Institutes of Health Consensus Meeting approving the use of liver transplantation as the treatment for end-stage liver disease. ${ }^{2}$ Over the next decade, further developments in immunosuppressant agents were made, and in 1994 the FK506 Liver Study Group reported results from their multicenter randomized controlled trial demonstrating a lower incidence of steroid-resistant acute rejection with tacrolimus compared to CsA-based immunosuppression regimen. ${ }^{3}$

Despite these early advances, acute rejection among liver transplant recipients remains a major source of morbidity and mortality, as the immunosupppression regimen capable of inducing or promoting immunologic tolerance continues to elude the transplant community. This has resulted in a lack of standardization with regard to immunosuppression regimen across centers. ${ }^{4}$ Current protocols have implemented many different strategies, including combinations of drugs with different modes of 
action to minimize side effects, ${ }^{5}$ steroid minimization, ${ }^{6,7}$ calcineurin inhibitor minimization or avoidance, ${ }^{8-10}$ and the use of induction therapy in the perioperative period to delay the introduction of maintenance immunosuppression. ${ }^{11}$ A report from the Scientific Registry of Transplant Recipients outlined the use of various immunosuppressive agents across centers. The report found that $18 \%$ of centers use induction antibody therapy, 97\% use calcineurin inhibitor (CNI) therapy, $90 \%$ use corticosteroids, $48 \%$ use mycophenolatemofetil (MMF), 4\% use azathioprine (AZA), and 7\% of centers use mTOR inhibitors. ${ }^{12,13}$

As outlined, currently no one standard immunosuppressive regimen exists in liver transplantation, yet the goal of therapy continues to be to reduce or eliminate acute cellular rejection while simultaneously limiting harmful side effects. There are various classes of immunosuppressive agents used in liver transplantation. Each is designed to disrupt the process along the complex path of acute cellular rejection, such as at the point of alloantigen recognition, ${ }^{14-16}$ T-cell activation, ${ }^{17}$ clonal expansion, and/ or graft inflammation. ${ }^{18}$ The following review will focus on and discuss the current use of immunosuppressive drugs in liver transplantation.

\section{Immunosuppressive agents}

Immunosuppressive agents are typically broadly classified as either induction agents or maintenance immunosuppression drugs (Table 1 and Figure 1). Induction therapy refers to those drugs given at the time of liver transplantation to profoundly quiet immune response during recovery from ischemia reperfusion injury and allows for delay of the introduction of maintenance agents. Induction drugs are classically steroids with or without the addition of biologic agents, such as potent monoclonal and polyclonal antibodies. Examples of induction agents include antithymocyte antibodies and anticytokine receptor antibodies. Recent data suggest that induction immunosuppression improves patient and graft survival among liver transplant recipients. ${ }^{19}$ Maintenance immunosuppressive agents are those used on a daily basis to attenuate the patient's immune response post-transplant. These agents include CNIs, mTOR inhibitors, corticosteroids, and antimetabolites.

\section{Induction agents}

\section{Antilymphocyte antibody therapy}

Antilymphocyte antibody therapy is also referred to as lymphoid depletion therapy as these antibodies have

Table I Therapeutic advantages and disadvantages of various immunosuppression agents

\begin{tabular}{|c|c|c|}
\hline Type of immunosuppression & Advantages & Disadvantages \\
\hline \multicolumn{3}{|l|}{ Induction agents } \\
\hline Antilymphocyte antibody & $\begin{array}{l}\text { Reduce the amount of maintenance } \\
\text { immunosuppression required }\end{array}$ & Hypotension, bronchospasm, fever, tachycardia \\
\hline $\begin{array}{l}\text { Anti-T-cell receptor antibodies } \\
\text { (OKT3) }\end{array}$ & $\begin{array}{l}\text { Superior to steroids and } \mathrm{CsA} \text { at reversing } \\
\text { acute cellular rejection }\end{array}$ & $\begin{array}{l}\text { Fever, hypotension, aseptic meningitis, flash } \\
\text { pulmonary edema; PTLD; acceleration of } \mathrm{HCV}\end{array}$ \\
\hline $\begin{array}{l}\text { Polyclonal antibodies } \\
\text { (ATGAM and thymoglobulin) }\end{array}$ & $\begin{array}{l}\text { Treat steroid resistant rejection; no impact on } \\
\mathrm{HCV} \text { recurrence; may promote immunologic } \\
\text { tolerance }\end{array}$ & $\begin{array}{l}\text { Lymphopenia; variations in clinical efficiency of } \\
\text { various preparations }\end{array}$ \\
\hline Alemtuzumab & $\begin{array}{l}\text { Reduce the amount of maintenance } \\
\text { immunosuppression required }\end{array}$ & $\begin{array}{l}\text { Associated with higher rates of vascular } \\
\text { rejection; profound lymphopenia }\end{array}$ \\
\hline Interleukin-2 receptor antibodies & $\begin{array}{l}\text { Reduce the amount of maintenance } \\
\text { immunosuppression required; No adverse } \\
\text { impact on HCV recurrence }\end{array}$ & $\begin{array}{l}\text { Monotherapy associated with increased rates } \\
\text { of acute cellular rejection and steroid-resistant } \\
\text { rejection }\end{array}$ \\
\hline \multicolumn{3}{|l|}{ Maintenance agents } \\
\hline Corticosteroids & Suppress antibody and complement binding & $\begin{array}{l}\text { Hypertension, osteoporosis, diabetes, impaired } \\
\text { wound healing }\end{array}$ \\
\hline $\begin{array}{l}\text { Calcineurin inhibitors } \\
\text { (CsA and tacrolimus) }\end{array}$ & Allow for steroid minimization & $\begin{array}{l}\text { Hypertension, nephrotoxicity, neurotoxicity, } \\
\text { hirsuitism, diabetes, lipid abnormalities }\end{array}$ \\
\hline m-TOR inhibitors (Sirolimus) & Less renal toxic effects & $\begin{array}{l}\text { Dose-related hyperlipidemia and cytopenias; } \\
\text { nephrotic syndrome; interstitial pneumonia; liver } \\
\text { function test abnormalities; wound dehiscence; } \\
\text { question of increased incidence of hepatic artery } \\
\text { thrombosis }\end{array}$ \\
\hline Purine synthesis inhibitors (MMF) & $\begin{array}{l}\text { Not associated with neurotoxicity or nephrotoxicity, } \\
\text { used as a calcineurin inhibitor sparing agent }\end{array}$ & Leukopenia and Gl disturbances \\
\hline
\end{tabular}

Abbreviations: CsA, cyclosporine; HCV, hepatitis C; MMF, mycophenolatemofetil; PTLD, post-transplant lymphoproliferative disorder. 


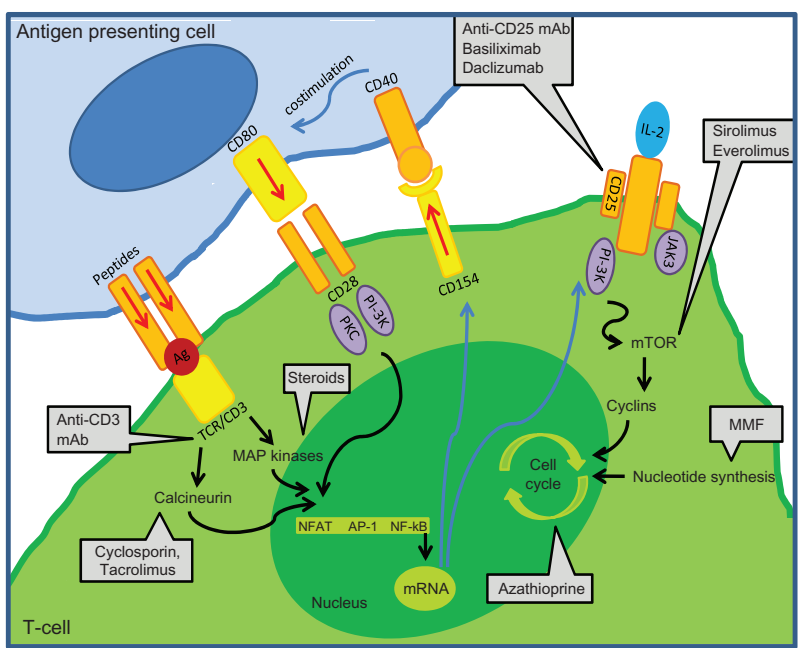

Figure I Mechanisms of action for various immunosuppression agents. Antigen presenting cells present antigen to T-cells, resulting in activation and costimulation of the T-cell. The activated T-cell then undergoes clonal expansion and differentiation to express a specific effector function.

Abbreviation: MMF, mycophenolatemofetil.

specificity for T- and B-cell antigens resulting in the elimination of these cell populations. ${ }^{20}$ As a result, lymphoid depletion is often reserved for either induction therapy to reduce the amount of maintenance immunosuppression required or to treat steroid resistant rejection. These antibodies elicit cytokine release from lymphocytes. Clinically this is 1 manifested as hypotension, bronchospasm, fever, and tachycardia. These side effects can be eliminated or reduced by premedication with steroids and antihistamines prior to administration. ${ }^{18}$

\section{Anti-T-cell receptor antibodies - muromonab-CD3 (OKT3)}

OKT3 is a monoclonal antibody that has a defined specificity to the CD3 receptor on mature T-cells, and has no impact on immature thymocytes..$^{21}$ The administration of OKT3 results in a greater than $55 \%$ decline in circulating CD3+ T-cells. ${ }^{22}$ The onset of action is within minutes, the drug persists for approximately 1 week, and the effects continue for weeks to months. There are severe side effects associated with the medication related to the release of proinflammatory cytokines, which include fever, hypotension, aseptic meningitis, and flash pulmonary edema. The potential for the development of these side effects is greatest with the first several doses of OKT3 administered. OKT3 administration has also been associated with higher rates of post-transplant lymphoproliferative disorder (PTLD) ${ }^{23,24}$ The development of PTLD is even more common among patients transplanted for hepatitis $\mathrm{C}(\mathrm{HCV})$ cirrhosis. ${ }^{25}$ Furthermore, there appears to be a rapid acceleration of $\mathrm{HCV}$ replication leading to earlier and more severe recurrent disease among patients undergoing liver transplantation for $\mathrm{HCV}$ cirrhosis. ${ }^{26}$ Despite these negative effects, OKT3 has been shown in several randomized controlled trials to be useful in steroidresistant rejections. ${ }^{27,28}$

\section{Polyclonal antibodies - ATGAM (Pfizer, New York, NY) and thymoglobulin (Genzyme, Boston, MA)}

Polyclonal antibodies are heterologous preparations made by immunizing animals with human T-cells and thymocytes. The purified gamma globulin fraction of the antisera is collected, which is also known as the antithymocyte globulin (ATG). Specifically ATG is directed against human thymocytes, which leads to depletion of peripheral lymphocytes and peripheral lymphopenia. Variations in the clinical efficiency of various ATG preparations have been well documented. It is believed that the polyclonal antibodies ability to recognize multiple cell surface molecules is responsible for this variation..$^{29,30}$ In general ATG has been primarily used as an induction agent, corticosteroid sparing agent, and as treatment for steroid resistant rejection. ${ }^{31,32}$ Although there is concern for use of ATG in patients with $\mathrm{HCV}$, there are no convincing data that they have a negative impact on $\mathrm{HCV}$ recurrence. ${ }^{33,34}$ Some studies have suggested that a regimen which includes ATG may promote immunologic tolerance, as ATG therapy has been shown to result in an expansion in regulatory T-cells. ${ }^{35-37}$

\section{Alemtuzumab - campath- IH (C-IH)}

$\mathrm{C}-1 \mathrm{H}$ is a humanized recombinant anti-CD52 monoclonal antibody. CD52 is a cell surface glycoprotein expressed on $95 \%$ of peripheral lymphocytes, monocytes, macrophages, and natural killer cells. ${ }^{38}$ Binding of CD52 by C-1 $\mathrm{H}$ results in profound depletion of circulating lymphocytes in blood and lymph nodes, with the exception of plasma and memory cells $.^{39,40} \mathrm{C}-1 \mathrm{H}$ was initially used as an induction agent to facilitate lower doses of maintenance immunosuppressant agents. ${ }^{41}$ However, $\mathrm{C}-1 \mathrm{H}$ did not prevent the development or lower the incidence of acute cellular rejection, ${ }^{42,43}$ and in fact, was associated with a higher rate of vascular rejection. ${ }^{44}$ Therefore, $\mathrm{C}-1 \mathrm{H}$ is not widely used in liver transplantation today. 
Interleukin-2 receptor antibodies basiliximab (Simulect, Novartis, Basel, Switzerland) and daclizumab (Zenapax, Hoffman-La Roche, Basel, Switzerland)

Interleukin-2 receptor (IL-2) antibodies are chimeric IgG1 monoclonal antibodies that are less immunogenic than other monoclonal antibodies such as OKT3. These antibodies bind the IL-2 receptor on activated T-cells, leading to inhibition of T-cell proliferation..$^{45}$ Of note, the half-life of IL-2 receptor antibodies is decreased in liver transplant recipients secondary to higher volume of distribution in patients with ascites. ${ }^{46}$ As a result, early trials reported acute cellular rejection rates as high as $35 \%$, which was attributed to activated T-cells bypassing the IL-2 receptor blockade. ${ }^{47-49}$ With proper dosing adjustments, more recent trials demonstrate no difference in incidence of acute cellular rejection..$^{50}$ There also appears to be no adverse impact on HCV recurrence and graft or patient survival, and in fact, there appears to be an improvement in renal function as IL-2 receptor antibody induction allows for lower doses of maintenance immunosuppression with calcineurin inhibitors (CNIs). ${ }^{22,50-55}$ It is important to note, however, that IL-2 receptor antibodies should always be used in combination with CNIs, as monotherapy has been associated with increased rates of acute cellular rejection and in particular steroid-resistant rejection. ${ }^{56}$

\section{Maintenance immunosuppression agents Corticosteroids}

Corticosteroids inhibit the production of T-cell cytokines, such as IL-2, IL-6, and interferon gamma, which are required to activate T-cells against alloantigen. In addition, corticosteroids also suppress antibody and complement binding and stimulate migration of T-cells from the intravascular compartment to lymphoid tissue. Prior to the introduction of CsA, corticosteroids were the main stay of immunosuppression. ${ }^{57-59}$ Since the introduction of CNIs, there has been a trend toward steroid minimization in an effort to reduce the adverse effects associated with prolonged steroid use, such as hypertension, osteoporosis, diabetes, and impaired wound healing. ${ }^{18}$ In fact more recent studies have shown that early tapering of steroids to CNI monotherapy does not adversely impact acute cellular rejection rates, graft, and/or patient survival, and does not increase the risk of graft fibrosis in the long term. ${ }^{6,7}$ Furthermore, steroid avoidance has proven beneficial in patients transplanted for $\mathrm{HCV}$ cirrhosis. However, studies have shown that rapid steroid taper can result in acute cellular rejection requiring rescue therapy which may promote rapid recurrence of $\mathrm{HCV}^{60-62}$

\section{Calcineurin inhibitors - cyclosporin (Neoral, Novartis) and tacrolimus (Prograf, FK506, Astellas Pharmaceuticals, Deerfield, IL)}

Both CsA and tacrolimus are CNIs that bind to their specific immunophilins, cyclophilin and FK binding proteins respectively. The drug-receptor complex then binds to and inhibits calcineurin, a phosphatase that regulates subcellular localization, and in turn activation, of transcription factors including nuclear factor of activated T-cells (NF-AT). Tacrolimus and Csa have similar side effect profiles. The most common side effects include hypertension, nephrotoxicity, neurotoxicity, hirsuitism, diabetes, and lipid abnormalities. ${ }^{63} \mathrm{~A}$ recent meta-analysis reported similar rates of patient and graft survival independent of which CNI used, ${ }^{64}$ although this remains a controversial topic within the liver transplant community.

The immunosuppressive activity of CsA was discovered in $1976,{ }^{65}$ and the drug was approved for use in liver transplantation in $1982 .{ }^{66,67}$ Initial studies demonstrated a $37 \%$ improvement in graft and patient survival at 1-year compared to the then standard immunosuppression regimen of AZA and corticosteroids ( $70 \%$ vs $33 \%)^{68}$ revolutionizing the field of liver transplantation. Further studies examining the mechanisms of action of the drug elucidated the ability of CsA to inhibit HCV replication in vitro. ${ }^{69}$ In fact several studies were able to demonstrate in vivo that CsA inhibited HCV in a dose-dependent fashion, CsA-treated patients had lower HCV RNA levels, and that compared to tacrolimus-based immunosuppression Ishak fibrosis scores and fibrosis grades were significantly lower in CsA-treated patients compared to tacrolimus-treated patients. ${ }^{70,71}$ However, current data do not support a beneficial effect of CsA over tacrolimus for the prevention of $\mathrm{HCV}$ recurrence after liver transplantation. ${ }^{72-74}$ Interestingly, a recent study has demonstrated higher de novo cancer risk among liver transplant recipients under the age of 50 years treated with CsA- versus tacrolimus-based maintenance immunosuppression. ${ }^{75}$

Tacrolimus is known to be 100 times more potent than CsA. ${ }^{76}$ Multiple studies have been performed comparing the efficacy of tacrolimus- and CsA-based immunosuppression regimen. Controversy remains as these studies often have 
conflicting conclusions. Three prospective randomized controlled clinical trials reported decreased incidence of acute cellular rejection with the use of tacrolimus compared to CsA, but no difference in patient and/or graft survival., 377,78 Grady and colleagues found tacrolimus to be more beneficial with regard to graft loss and rejection but not patient death or retransplant. ${ }^{73}$ Their work was later supported in several meta-analyses. ${ }^{79,80}$ Renal dysfunction is a well-known complication of tacrolimus-based immunosuppression. Multiple studies have documented that tapering of tacrolimus dose and/or discontinuation of tacrolimus-based immunosuppression results in significant improvement in renal function. ${ }^{81-83}$ In fact, one study demonstrated a $63 \%$ improvement in the glomerular filtration rate at 1 -year after cessation of CNIs. ${ }^{81}$

\section{mTOR inhibitor - sirolimus (Rapamycin, Wyeth-Ayerst, Madison, NJ) and everolimus (Afinitor, Novartis)}

Sirolimus binds the mammalian target of rapamycin (mTOR), which blocks IL-2 induction of B- and T-cell proliferation by preventing the progression of the cell cycle from $\mathrm{G} 1$ to $\mathrm{S}$ phase. ${ }^{84,85}$ The most common side effects associated with sirolimus include dose-related hyperlipidemia and cytopenias. ${ }^{86,87}$ Less common side effects include the development of proteinuria leading to nephrotic syndrome, ${ }^{88,89}$ interstitial pneumonia,${ }^{90}$ and in some patients, liver function test abnormalities. ${ }^{91}$ An associated increased risk of wound dehiscence and hepatic artery thrombosis (HAT) with the use of sirolimus has also been reported, particularly in the first post-transplant month. ${ }^{92-94}$ Subsequent larger series, however, have failed to demonstrate increased HAT. ${ }^{95}$ Sirolimus may prevent hepatic fibrosis, and therefore, prevent or delay cirrhosis. ${ }^{96}$ However, sirolimus does not significantly affect the timing or severity of $\mathrm{HCV}$ recurrence post-liver transplant. ${ }^{97}$ Sirolimus has also been documented to have anticancer effects and its use has been associated with improved survival among patients transplanted with hepatocellular carcinomas. ${ }^{98-100}$ Sirolimus is known to have a long half-life and narrow therapeutic window, and as a result, frequent drug monitoring is required. A newer agent everolimus has improved pharmacokinetic properties. Everolimus has a good safety profile and has been shown to be efficacious in preventing acute cellular rejection in a calcineurin inhibitor-free immunosuppressive regimen. ${ }^{101}$

Early reports found that acute cellular rejection was more common with monotherapy. ${ }^{102}$ However, subsequent studies noted that with the addition of corticosteroids to sirolimus maintenance immunosuppression, lower rates of acute cellular rejection can be achieved along with excellent patient and graft survival. ${ }^{103-107}$ Sirolimus is thought to have less renal toxic effects compared to CNI-based immunosuppression. However, controversy exists about the nephrotoxic sparing effects of sirolimus. Several single center studies demonstrated improved renal function when switching from CNI alone to low-dose CNI plus sirolimus or sirolimus monotherapy. ${ }^{108,109}$ In fact, one of the studies documented a $71 \%$ improvement in renal function. ${ }^{109}$ Contrary to these reports, several randomized controlled trials and a case controlled study have demonstrated no difference in renal function at 1-year when switching from CNI-based to a sirolimus-based immunosuppression regimen. ${ }^{110-112}$ It appears as though the renal-sparing effects of sirolimus-based immunosuppression therapy are more likely to be achieved when treatment is initiated early in the post-transplant period prior to CNI toxicity developing. ${ }^{113-116}$

\section{Purine synthesis inhibitors - mycophenolatemofetil (Cellcept, Roche) and enteric-coated mycophenolate sodium (Myfortic, Novartis)}

Replacing the prototypical agent of this class, azathioprine, MMF blocks de novo purine nucleotide synthesis by inhibiting the production of guanasine nucleotides, such as guanasine monophosphate. ${ }^{117,118}$ Cells lacking guanasine monophosphate cannot synthesize guanine triphosphate, and therefore cannot replicate unless they are able to maintain guanine triphosphate levels via the purine salvage pathway. T- and B-cells lack a key enzyme in the salvage pathway, and therefore cannot replicate in the presence of MMF. ${ }^{119} \mathrm{MMF}$ is hydrolyzed to its active form mycophenolic acid (MPA). ${ }^{120,121}$ Interestingly, food decreases the bioavailability of MPA, and therefore, MMF should be administered at least 1 hour before or 2 hours after meals. ${ }^{18}$ In addition, variations in serum albumin levels, as seen in liver transplant patients, can lead to fluctuations in MMF pharmacokinetics. ${ }^{122}$ The most common side effects of MMF administration are leucopenia and GI disturbances. ${ }^{123,124} \mathrm{MMF}$ does not cause nephrotoxicity or neurotoxicity, and as a result, has been used as a CNIsparing agent. ${ }^{125-127}$

Currently, there does not appear to be a role for MMF monotherapy in liver transplantation as there is an associated 
unacceptably high incidence of acute cellular rejection, severe chronic rejection, and steroid-resistant rejection. ${ }^{128,129}$ However, when added to a $\mathrm{CNI} /$ corticosteroid-based immunosuppression regimen, lower rates of acute cellular rejection can be achieved. ${ }^{130}$ Furthermore, it has been observed to reverse steroid-resistant rejection when added to a $\mathrm{CNI} /$ corticosteroid-based immunosuppression regimen. ${ }^{131,132}$ In fact, in one study, $81 \%$ of patients with cellular rejection had normalization of their liver function tests. ${ }^{132}$ It has also been shown in a recent Scientific Registry for Transplant Recipients database analysis to be an important factor in improved outcomes among liver transplant recipients on tacrolimus-based immunosuppression regimen. ${ }^{133}$ Current data suggest that MMF has no impact on $\mathrm{HCV}$ recurrence. ${ }^{134}$

\section{Induction of immune tolerance}

Current immunosuppressive strategies have resulted in improved allograft survival. However, long-term immunosuppression is associated with increased risk of infection, development of cancer, and even cardiovascular disease. In addition, current immunosuppressive strategies cannot reliably prevent chronic allograft injury. Overcoming the problems associated with long-term immunosuppressive strategies would require the development of a state of immune tolerance or a state in which there is graft acceptance in the absence of immune suppression. Many clinical protocols have been developed to facilitate immune tolerance, including the use of hematopoietic cells as tolerance inducing antigens, ${ }^{135}$ establishment of mixed chimerism, ${ }^{136}$ pretransplant total irradiation, ${ }^{137}$ lymphocyte depletion, ${ }^{138}$ and costimulation blockade. ${ }^{139}$ Unfortunately, while these protocols have been successful in small animal models, the findings have not translated to similar results in humans. Recently, Scandling et al published a case series describing the ability to eliminate the need for immunosuppression after combined bone marrow and kidney transplants from a human leukocyte antigen matched donor, providing insight into a potential mechanism for inducing tolerance in liver transplant recipients. ${ }^{140}$

\section{Conclusion}

Advances in immunosuppression have revolutionized the field of liver transplantation over the last 30 years. Immunologic tolerance has yet to be achieved, and as such, the success of liver transplantation in the immediate future will continue to depend on the discovery and implementation of newer immunosuppressant agents. This will require continued rigor within the field with regard to the use of randomized controlled trials. Finally, continued attention will need to be paid to the impact of immunosuppression on HCV recurrence, as HCV remains the most common indication for liver transplantation in the United States.

\section{Disclosure}

No conflicts of interest were declared in relation to this paper.

\section{References}

1. Calne RY, White DJ, Thiru S, Rolles K, Drakopoulos S, Jamieson NV. Cyclosporin G: immunosuppressive effect in dogs with renal allografts. Lancet. 1985;1(8441):1342.

2. Liver transplantation. National Institutes of Health Consensus Development. Paper presented at: National Institutes of Health Consensus Development Conference Summary; 1983.

3. A comparison of tacrolimus (FK 506) and cyclosporine for immunosuppression in liver transplantation. The US Multicenter FK506 Liver Study Group. N Engl J Med. 1994;331(17):1110-1115.

4. Demetris AJ, Adeyi O, Bellamy CO, et al. Liver biopsy interpretation for causes of late liver allograft dysfunction. Hepatology. 2006;44(2): 489-501.

5. Sharma VK, Li B, Khanna A, Sehajpal PK, Suthanthiran M. Which way for drug-mediated immunosuppression? Curr Opin Immunol. 1994;6(5):784-790.

6. Manzia TM, Toti L, Angelico R, Di Cocco P, Orlando G, Tisone G. Steroid-free immunosuppression after liver transplantation does not increase the risk of graft fibrosis. Transplant Proc. 2010;42(4): 1237-1239.

7. Weiler N, Thrun I, Hoppe-Lotichius M, Zimmermann T, Kraemer I, Otto G. Early steroid-free immunosuppression with FK506 after liver transplantation: long-term results of a prospectively randomized doubleblinded trial. Transplantation. 2010;90(12):1562-1566.

8. Gonwa TA, Mai ML, Melton LB, et al. End-stage renal disease (ESRD) after orthotopic liver transplantation (OLTX) using calcineurin-based immunotherapy: risk of development and treatment. Transplantation. 2001;72(12):1934-1939.

9. Jain AB, Yee LD, Nalesnik MA, et al. Comparative incidence of de novo nonlymphoid malignancies after liver transplantation under tacrolimus using surveillance epidemiologic end result data. Transplantation. 1998;66(9):1193-1200.

10. Ojo AO, Held PJ, Port FK, et al. Chronic renal failure after transplantation of a nonrenal organ. $N$ Engl J Med. 2003;349(10):931-940.

11. Asrani SK, Kim WR, Pedersen RA, et al. Daclizumab induction therapy in liver transplant recipients with renal insufficiency. Aliment Pharmacol Ther. 2010;32(6):776-786.

12. Organ Procurement and Transplantation Network/Scientific Registry of Transplant Recipients Annual Report: Transplant Data 19932002. In: US Department of Health and Human Services HRaSA, Special Programs Bureau, Division of Transplantation, Division of Transplantation; United Network for Organ Sharing; University Renal Research and Education Association, ed; 2003.

13. Kaufman DB, Shapiro R, Lucey MR, Cherikh WS, Bastami RT, Dyke D. Immunosuppression: practice and trends. Am J Transplant. 2004;4(Suppl 9):38-53.

14. Choudhuri K, Wiseman D, Brown MH, Gould K, van der Merwe PA. T-cell receptor triggering is critically dependent on the dimensions of its peptide-MHC ligand. Nature. 2005;436(7050):578-582. 
15. Rubin B, Riond J, Leghait J, Gairin JE. Interactions between CD8alphabeta and the TCRalphabeta/CD3-receptor complex. Scand J Immunol. 2006;64(3):260-270.

16. Zheng H, Jin B, Henrickson SE, Perelson AS, von Andrian UH, Chakraborty AK. How antigen quantity and quality determine T-cell decisions in lymphoid tissue. Mol Cell Biol. 2008;28(12): 4040-4051.

17. O'Shea JJ, Johnston JA, Kehrl J, Koretzky G, Samelson LE. Key molecules involved in receptor-mediated lymphocyte activation. Curr Protoc Immunol. 2001; Chapter 11:Unit 11 19A.

18. Mukherjee S, Mukherjee U. A comprehensive review of immunosuppression used for liver transplantation. J Transplant. 2009: 701464.

19. Cai J, Terasaki PI. Induction immunosuppression improves long-term graft and patient outcome in organ transplantation: an analysis of United Network for Organ Sharing registry data. Transplantation. 2010;90(12):1511-1515.

20. Starzl TE, Koep LJ, Halgrimson CG, et al. Liver transplantation - 1978. Transplant Proc. 1979;11(1):240-246.

21. Kung P, Goldstein G, Reinherz EL, Schlossman SF. Monoclonal antibodies defining distinctive human T cell surface antigens. Science. 1979;206(4416):347-349.

22. KlintmalmSCaG. Transplantation of the liver. Philadelphia, PA: Elsevier; 2005.

23. Kremers WK, Devarbhavi HC, Wiesner RH, Krom RA, Macon WR, Habermann TM. Post-transplant lymphoproliferative disorders following liver transplantation: incidence, risk factors and survival. $\mathrm{Am} \mathrm{J}$ Transplant. 2006;6(5 Pt 1):1017-1024.

24. Sanchez EQ, Marubashi S, Jung G, et al. De novo tumors after liver transplantation: a single-institution experience. Liver Transpl. 2002; 8(3):285-291.

25. McLaughlin K, Wajstaub S, Marotta P, et al. Increased risk for posttransplant lympho proliferative disease in recipients of liver transplants with hepatitis C. Liver Transpl. 2000;6(5):570-574.

26. Rosen HR, Shackleton CR, Higa L, et al. Use of OKT3 is associated with early and severe recurrence of hepatitis $\mathrm{C}$ after liver transplantation. Am J Gastroenterol. 1997;92(9):1453-1457.

27. Cosimi AB, Cho SI, Delmonico FL, Kaplan MM, Rohrer RJ, Jenkins RL. A randomized clinical trial comparing OKT3 and steroids for treatment of hepatic allograft rejection. Transplantation. 1987;43(1): 91-95.

28. Farges O, Ericzon BG, Bresson-Hadni S, et al. A randomized trial of OKT3-based versus cyclosporine-based immunoprophylaxis after liver transplantation. Long-term results of a European and Australian multicenter study. Transplantation. 1994;58(8):891-898.

29. Michallet MC, Preville X, Flacher M, Fournel S, Genestier L, Revillard JP. Functional antibodies to leukocyte adhesion molecules in antithymocyte globulins. Transplantation. 2003;75(5):657-662.

30. Rebellato LM, Gross U, Verbanac KM, Thomas JM. A comprehensive definition of the major antibody specificities in polyclonal rabbit antithymocyte globulin. Transplantation. 1994;57(5):685-694.

31. Eason JD, Loss GE, Blazek J, Nair S, Mason AL. Steroid-free liver transplantation using rabbit antithymocyte globulin induction: results of a prospective randomized trial. Liver Transpl. 2001;7(8): 693-697.

32. Eason JD, Nair S, Cohen AJ, Blazek JL, Loss GE Jr. Steroid-free liver transplantation using rabbit antithymocyte globulin and early tacrolimusmonotherapy. Transplantation. 2003;75(8):1396-1399.

33. De Ruvo N, Cucchetti A, Lauro A, et al. Preliminary results of a "prope" tolerogenic regimen with thymoglobulin pretreatment and hepatitis $\mathrm{C}$ virus recurrence in liver transplantation. Transplantation. 2005; 80(1):8-12.

34. Nair S, Loss GE, Cohen AJ, Eason JD. Induction with rabbit antithymocyte globulin versus induction with corticosteroids in liver transplantation: impact on recurrent hepatitis $\mathrm{C}$ virus infection. Transplantation. 2006;81(4):620-622.
35. Feng X, Kajigaya S, Solomou EE, et al. Rabbit ATG but not horse ATG promotes expansion of functional CD4+CD25highFOXP3+ regulatory T cells in vitro. Blood. 2008;111(7):3675-3683.

36. Lopez M, Clarkson MR, Albin M, Sayegh MH, Najafian N. A novel mechanism of action for anti-thymocyte globulin: induction of CD4+CD25+Foxp3+ regulatory T cells. J Am Soc Nephrol. 2006; 17(10):2844-2853.

37. Lytton SD, Denton CP, Nutzenberger AM. Treatment of autoimmune disease with rabbit anti-T lymphocyte globulin: clinical efficacy and potential mechanisms of action. Ann N Y Acad Sci. 2007;1110: 285-296.

38. Frampton JE, Wagstaff AJ. Alemtuzumab. Drugs. 2003;63(12): 1229-1243; discussion 1245-1226.

39. Calne RY. Prope tolerance: a step in the search for tolerance in the clinic. World J Surg. 2000;24(7):793-796.

40. Magliocca JF, Knechtle SJ. The evolving role of alemtuzumab (Campath-1H) for immunosuppressive therapy in organ transplantation. Transpl Int. 2006;19(9):705-714.

41. Calne R, Friend P, Moffatt S, et al. Prope tolerance, perioperative campath $1 \mathrm{H}$, and low-dose cyclosporinmonotherapy in renal allograft recipients. Lancet. 1998;351(9117):1701-1702.

42. Kirk AD, Mannon RB, Kleiner DE, et al. Results from a human renal allograft tolerance trial evaluating T-cell depletion with alemtuzumab combined with deoxyspergualin. Transplantation. 2005;80(8) 1051-1059.

43. Tzakis AG, Kato T, Nishida S, et al. Preliminary experience with campath $1 \mathrm{H}(\mathrm{C} 1 \mathrm{H})$ in intestinal and liver transplantation. Transplantation. 2003;75(8):1227-1231.

44. Knechtle SJ, Pirsch JD, Fechner JH Jr, et al. Campath-1H induction plus rapamycinmonotherapy for renal transplantation: results of a pilot study. Am J Transplant. 2003;3(6):722-730.

45. Vincenti F. Targeting the interleukin-2 receptor in clinical renal transplantation. Graft. 1999;2:56-61.

46. Moser MA. Options for induction immunosuppression in liver transplant recipients. Drugs. 2002;62(7):995-1011.

47. Calmus Y, Scheele JR, Gonzalez-Pinto I, et al. Immunoprophylaxis with basiliximab, a chimeric anti-interleukin-2 receptor monoclonal antibody, in combination with azathioprine-containing triple therapy in liver transplant recipients. Liver Transpl. 2002;8(2):123-131.

48. Kwekkeboom J, Warle MC, Rietveld J, Segeren KC, Tilanus HW, Metselaar HJ. Blockade of intragraft IL-2 receptor-alpha by basiliximab is insufficient to prevent activation of liver graft infiltrating cells. Transpl Immunol. 2003;11(1):1-5.

49. Neuhaus P, Clavien PA, Kittur D, et al. Improved treatment response with basiliximabimmunoprophylaxis after liver transplantation: results from a double-blind randomized placebo-controlled trial. Liver Transpl. 2002;8(2):132-142.

50. Schmeding M, Sauer IM, Kiessling A, et al. Influence of basiliximab induction therapy on long term outcome after liver transplantation, a prospectively randomised trial. Ann Transplant. 2007;12(3): 15-21.

51. Eckhoff DE, McGuire B, Sellers M, et al. The safety and efficacy of a two-dose daclizumab (zenapax) induction therapy in liver transplant recipients. Transplantation. 2000;69(9):1867-1872.

52. Emre S, Gondolesi G, Polat K, et al. Use of daclizumab as initial immunosuppression in liver transplant recipients with impaired renal function. Liver Transpl. 2001;7(3):220-225.

53. Filipponi F, Callea F, Salizzoni M, et al. Double-blind comparison of hepatitis $\mathrm{C}$ histological recurrence rate in $\mathrm{HCV}+$ liver transplant recipients given basiliximab + steroids or basiliximab + placebo, in addition to cyclosporine and azathioprine. Transplantation. 2004; 78(10):1488-1495.

54. Kato T, Gaynor JJ, Yoshida H, et al. Randomized trial of steroid-free induction versus corticosteroid maintenance among orthotopic liver transplant recipients with hepatitis $\mathrm{C}$ virus: impact on hepatic fibrosis progression at one year. Transplantation. 2007;84(7):829-835. 
55. Alakkari A, Maguire D, Geoghegan J, et al. Anti-CD25 antibodies (daclizumab) as renal sparing immunosuppression after liver transplantation. Aliment Pharmacol Ther. 2011;33(5):615-616.

56. Hirose R, Roberts JP, Quan D, et al. Experience with daclizumab in liver transplantation: renal transplant dosing without calcineurin inhibitors is insufficient to prevent acute rejection in liver transplantation. Transplantation. 2000;69(2):307-311.

57. Morgan JA. The influence for cortisone on the survival of homografts of skin in the rabbit. Surgery. 1951;30(3):506-515.

58. Murray JE, Merrill JP, Harrison JH, Wilson RE, Dammin GJ. Prolonged survival of human-kidney homografts by immunosuppressive drug therapy. N Engl J Med. 1963;268:1315-1323.

59. Starzl TE, Marchioro TL, Waddell WR. The reversal of rejection in human renal homografts with subsequent development of homograft tolerance. Surg Gynecol Obstet. 1963;117:385-395.

60. Brillanti S, Vivarelli M, De Ruvo N, et al. Slowly tapering off steroids protects the graft against hepatitis $\mathrm{C}$ recurrence after liver transplantation. Liver Transpl. 2002;8(10):884-888.

61. Brown RS Jr. Steroids in recurrent hepatitis $\mathrm{C}$ following liver transplantation: pitfall or panacea? J Hepatol. 2007;47(6):741-743.

62. Vivarelli M, Burra P, La Barba G, et al. Influence of steroids on HCV recurrence after liver transplantation: a prospective study. $J$ Hepatol. 2007;47(6):793-798.

63. Hong F, Lee J, Piao YJ, et al. Transgenic mice overexpressing cyclophilin A are resistant to cyclosporin A-induced nephrotoxicity via peptidyl-prolylcis-trans isomerase activity. Biochem Biophys Res Commun. 2004;316(4):1073-1080.

64. Berenguer M, Royuela A, Zamora J. Immunosuppression with calcineurin inhibitors with respect to the outcome of HCV recurrence after liver transplantation: results of a meta-analysis. Liver Transpl. 2007; 13(1):21-29.

65. Borel JF, Feurer C, Gubler HU, Stahelin H. Biological effects of cyclosporin A: a new antilymphocytic agent. Agents Actions. 1976;6(4): 468-475.

66. Calne RY. Liver transplantation. Ann Clin Res. 1981;13(4-5): 327-335.

67. Starzl TE, Koep L, Porter KA, et al. Decline in survival after liver transplantation. Arch Surg. 1980;115(7):815-819.

68. Gordon RD, Shaw BW Jr, Iwatsuki S, Esquivel CO, Starzl TE. Indications for liver transplantation in the cyclosporine era. Surg Clin North Am. 1986;66(3):541-556.

69. Henry SD, Metselaar HJ, Lonsdale RC, et al. Mycophenolic acid inhibits hepatitis $\mathrm{C}$ virus replication and acts in synergy with cyclosporin $\mathrm{A}$ and interferon-alpha. Gastroenterology. 2006;131(5):1452-1462.

70. Firpi RJ, Zhu H, Morelli G, et al. Cyclosporine suppresses hepatitis C virus in vitro and increases the chance of a sustained virological response after liver transplantation. Liver Transpl. 2006;12(1): 51-57.

71. van der Laan LJ, Hudson M, McPherson S, et al. Results of a two-center study comparing hepatic fibrosis progression in HCV-positive liver transplant patients receiving cyclosporine or tacrolimus. Transplant Proc. 2010;42(10):4573-4577.

72. Berenguer M, Aguilera V, San Juan F, et al. Effect of calcineurin inhibitors in the outcome of liver transplantation in hepatitis C virus-positive recipients. Transplantation. 2010;90(11):1204-1209.

73. O'Grady JG, Hardy P, Burroughs AK, Elbourne D. Randomized controlled trial of tacrolimus versus microemulsifiedcyclosporin (TMC) in liver transplantation: poststudy surveillance to 3 years. Am JTransplant. 2007;7(1):137-141.

74. Pan Q, Metselaar HJ, de Ruiter P, et al. Calcineurin inhibitor tacrolimus does not interfere with the suppression of hepatitis $C$ virus infection by interferon-alpha. Liver Transpl. 2010;16(4):520-526.

75. Tjon AS, SintNicolaas J, Kwekkeboom J, et al. Increased incidence of early de novo cancer in liver graft recipients treated with cyclosporine: an association with $\mathrm{C} 2$ monitoring and recipient age. Liver Transpl. 2010;16(7):837-846.
76. Goto T, Kino T, Hatanaka H, et al. Discovery of FK-506, a novel immunosuppressant isolated from Streptomyces tsukubaensis. Transplant Proc. 1987;19(5 Suppl 6):4-8.

77. European FK506 Multicentre Liver Study Group. Randomised trial comparing tacrolimus (FK506) and cyclosporin in prevention of liver allograft rejection. Lancet. 1994;344(8920):423-428.

78. Fung JJ, Eliasziw M, Todo S, et al. The Pittsburgh randomized trial of tacrolimus compared to cyclosporine for hepatic transplantation. J Am Coll Surg. 1996;183(2):117-125.

79. Haddad EM, McAlister VC, Renouf E, Malthaner R, Kjaer MS, Gluud LL. Cyclosporin versus tacrolimus for liver transplanted patients. Cochrane Database Syst Rev. 2006;4:CD005161.

80. McAlister VC, Haddad E, Renouf E, Malthaner RA, Kjaer MS, Gluud LL. Cyclosporin versus tacrolimus as primary immunosuppressant after liver transplantation: a meta-analysis. Am J Transplant. 2006; 6(7):1578-1585.

81. Herlenius G, Felldin M, Norden G, et al. Conversion from calcineurin inhibitor to either mycophenolatemofetil or sirolimus improves renal function in liver transplant recipients with chronic kidney disease: results of a prospective randomized trial. Transplant Proc. 2010;42(10): $4441-4448$

82. Kornberg A, Kupper B, Thrum K, et al. Sustained renal response to mycophenolatemofetil and CNI taper promotes survival in liver transplant patients with CNI-related renal dysfunction. Dig Dis Sci. 2010;56(1):244-251.

83. Masetti M, Montalti R, Rompianesi G, et al. Early withdrawal of calcineurin inhibitors and everolimusmonotherapy in de novo liver transplant recipients preserves renal function. Am J Transplant. 2010; 10(10):2252-2262.

84. Neuhaus P, Klupp J, Langrehr JM. mTOR inhibitors: an overview. Liver Transpl. 2001;7(6):473-484.

85. Raught B, Gingras AC, Gygi SP, et al. Serum-stimulated, rapamycinsensitive phosphorylation sites in the eukaryotic translation initiation factor 4GI. Embo J. 2000;19(3):434-444.

86. Groth CG, Backman L, Morales JM, et al. Sirolimus (rapamycin)based therapy in human renal transplantation: similar efficacy and different toxicity compared with cyclosporine. Sirolimus European Renal Transplant Study Group. Transplantation. 1999;67(7): 1036-1042.

87. Trotter JF, Wachs ME, Trouillot TE, et al. Dyslipidemia during sirolimus therapy in liver transplant recipients occurs with concomitant cyclosporine but not tacrolimus. Liver Transpl. 2001;7(5): 401-408.

88. Kahan BD. Efficacy of sirolimus compared with azathioprine for reduction of acute renal allograft rejection: a randomisedmulticentre study. The Rapamune US Study Group. Lancet. 2000;356(9225): 194-202.

89. Napoli KL, Wang ME, Stepkowski SM, Kahan BD. Relative tissue distributions of cyclosporine and sirolimus after concomitant peroral administration to the rat: evidence for pharmacokinetic interactions. Ther Drug Monit. 1998;20(2):123-133.

90. Flores-Franco RA, Luevano-Flores E, Gaston-Ramirez C. Sirolimusassociated desquamative interstitial pneumonia. Respiration. 2007; 74(2):237-238

91. Neff GW, Ruiz P, Madariaga JR, et al. Sirolimus-associated hepatotoxicity in liver transplantation. Ann Pharmacother. 2004;38(10): 1593-1596.

92. Dean PG, Lund WJ, Larson TS, et al. Wound-healing complications after kidney transplantation: a prospective, randomized comparison of sirolimus and tacrolimus. Transplantation. 2004;77(10):1555-1561.

93. Dunkelberg JC, Trotter JF, Wachs M, et al. Sirolimus as primary immunosuppression in liver transplantation is not associated with hepatic artery or wound complications. Liver Transpl. 2003;9(5): 463-468.

94. Fung J, Marcos A. Rapamycin: friend, foe, or misunderstood? Liver Transpl. 2003;9(5):469-472. 
95. Molinari M, Berman K, Meeberg G, et al. Multicentric outcome analysis of sirolimus-based immunosuppression in 252 liver transplant recipients. Transpl Int. 2010;23(2):155-168.

96. Zhu J, Wu J, Frizell E, et al. Rapamycin inhibits hepatic stellate cell proliferation in vitro and limits fibrogenesis in an in vivo model of liver fibrosis. Gastroenterology. 1999;117(5):1198-1204.

97. Asthana S, Toso C, Meeberg G, et al. The impact of sirolimus on hepatitis $\mathrm{C}$ recurrence after liver transplantation. Can J Gastroenterol. 2011;25(1):28-34.

98. Schnitzbauer AA, Zuelke C, Graeb C, et al. A prospective randomised, open-labeled, trial comparing sirolimus-containing versus mTORinhibitor-free immunosuppression in patients undergoing liver transplantation for hepatocellular carcinoma. BMC Cancer. 2010; 10:190.

99. Toso C, Merani S, Bigam DL, Shapiro AM, Kneteman NM. Sirolimusbased immunosuppression is associated with increased survival after liver transplantation for hepatocellular carcinoma. Hepatology. 2010; 51(4):1237-1243.

100. Zimmerman MA, Trotter JF, Wachs M, et al. Sirolimus-based immunosuppression following liver transplantation for hepatocellular carcinoma. Liver Transpl. 2008;14(5):633-638.

101. Saliba F, Dharancy S, Lorho R, et al. Conversion to everolimus in maintenance liver transplant patients: a multicenter retrospective analysis. Liver Transpl. 2011 Mar 7. [Epub ahead of print]

102. Watson CJ, Friend PJ, Jamieson NV, et al. Sirolimus: a potent new immunosuppressant for liver transplantation. Transplantation. 1999; 67(4):505-509

103. MacDonald AS. Rapamycin in combination with cyclosporine or tacrolimus in liver, pancreas, and kidney transplantation. Transplant Proc. 2003;35(3 Suppl):201S-208S.

104. McAlister VC, Gao Z, Peltekian K, Domingues J, Mahalati K, MacDonald AS. Sirolimus-tacrolimus combination immunosuppression. Lancet. 2000;355(9201):376-377.

105. McAlister VC, Peltekian KM, Malatjalian DA, et al. Orthotopic liver transplantation using low-dose tacrolimus and sirolimus. Liver Transpl. 2001;7(8):701-708.

106. Pridohl O, Heinemann K, Hartwig T, et al. Low-dose immunosuppression with FK 506 and sirolimus after liver transplantation: 1-year results. Transplant Proc. 2001;33(7-8):3229-3231.

107. Trotter JF, Wachs M, Bak T, et al. Liver transplantation using sirolimus and minimal corticosteroids (3-day taper). Liver Transpl. 2001;7(4):343-351

108. Casas-Melley AT, Falkenstein KP, Flynn LM, Ziegler VL, Dunn SP. Improvement in renal function and rejection control in pediatric liver transplant recipients with the introduction of sirolimus. Pediatr Transplant. 2004;8(4):362-366.

109. Fairbanks KD, Eustace JA, Fine D, Thuluvath PJ. Renal function improves in liver transplant recipients when switched from a calcineurin inhibitor to sirolimus. Liver Transpl. 2003;9(10) 1079-1085.

110. DuBay D, Smith RJ, Qiu KG, Levy GA, Lilly L, Therapondos G. Sirolimus in liver transplant recipients with renal dysfunction offers no advantage over low-dose calcineurin inhibitor regimens. Liver Transpl. 2008;14(5):651-659.

111. Shenoy S, Hardinger KL, Crippin J, et al. Sirolimus conversion in liver transplant recipients with renal dysfunction: a prospective, randomized, single-center trial. Transplantation. 2007;83(10): 1389-1392.

112. Watson CJ, Gimson AE, Alexander GJ, et al. A randomized controlled trial of late conversion from calcineurin inhibitor (CNI)-based to sirolimus-based immunosuppression in liver transplant recipients with impaired renal function. Liver Transpl. 2007;13(12):1694-1702.

113. Harper SJ, Gelson W, Harper IG, Alexander GJ, Gibbs P. Switching to sirolimus-based immune suppression after liver transplantation is safe and effective: a single-center experience. Transplantation. 2010 Oct 28. [Epub ahead of print].
114. Martinez JM, Pulido LB, Bellido CB, et al. Rescue immunosuppression with mammalian target of rapamycin inhibitor drugs in liver transplantation. Transplant Proc. 2010;42(2):641-643.

115. Schleicher C, Palmes D, Utech M, et al. Timing of conversion to mammalian target of rapamycin inhibitors is crucial in liver transplant recipients with impaired renal function at transplantation. Transplant Proc. 2010;42(7):2572-2575.

116. Vivarelli M, Dazzi A, Cucchetti A, et al. Sirolimus in liver transplant recipients: a large single-center experience. Transplant Proc. 2010; 42(7):2579-2584.

117. Franklin TJ, Cook JM. The inhibition of nucleic acid synthesis by mycophenolic acid. Biochem J. 1969;113(3):515-524.

118. Sintchak MD, Fleming MA, Futer O, et al. Structure and mechanism of inosine monophosphate dehydrogenase in complex with the immunosuppressant mycophenolic acid. Cell. 1996;85(6):921-930.

119. Hood KA, Zarembski DG. Mycophenolate mofetil: a unique immunosuppressive agent. Am J Health Syst Pharm. 1997;54(3):285-294.

120. Platz KP, Sollinger HW, Hullett DA, Eckhoff DE, Eugui EM, Allison AC. RS-61443 - a new, potent immunosuppressive agent. Transplantation. 1991;51(1):27-31.

121. Pescovitz MD, Conti D, Dunn J, et al. Intravenous mycophenolate mofetil: safety, tolerability, and pharmacokinetics. Clin Transplant. 2000;14(3):179-188.

122. Jain A, Venkataramanan R, Hamad IS, et al. Pharmacokinetics of mycophenolic acid after mycophenolate mofetil administration in liver transplant patients treated with tacrolimus. J Clin Pharmacol. 2001;41(3):268-276.

123. Budde K, Curtis J, Knoll G, et al. Enteric-coated mycophenolate sodium can be safely administered in maintenance renal transplant patients: results of a 1-year study. Am J Transplant. 2004;4(2):237-243.

124. Schmidt H, Brockmann J. MMF to EC-MPS conversion: what makes the difference? Liver Transpl. 2007;13(5):773-774; author reply 775 .

125. Barkmann A, Nashan B, Schmidt HH, et al. Improvement of acute and chronic renal dysfunction in liver transplant patients after substitution of calcineurin inhibitors by mycophenolate mofetil. Transplantation. 2000;69(9):1886-1890.

126. Klupp J, Bechstein WO, Platz KP, et al. Mycophenolate mofetil added to immunosuppression after liver transplantation - first results. Transpl Int. 1997;10(3):223-228.

127. Stegall MD, Wachs ME, Everson G, et al. Prednisone withdrawal 14 days after liver transplantation with mycophenolate: a prospective trial of cyclosporine and tacrolimus. Transplantation. 1997;64(12): 1755-1760.

128. Schlitt HJ, Barkmann A, Boker KH, et al. Replacement of calcineurin inhibitors with mycophenolate mofetil in liver-transplant patients with renal dysfunction: a randomised controlled study. Lancet. 2001; 357(9256):587-591.

129. Stewart SF, Hudson M, Talbot D, Manas D, Day CP. Mycophenolate mofetil monotherapy in liver transplantation. Lancet. 2001;357(9256): 609-610.

130. Jain AB, Hamad I, Rakela J, et al. A prospective randomized trial of tacrolimus and prednisone versus tacrolimus, prednisone, and mycophenolate mofetil in primary adult liver transplant recipients: an interim report. Transplantation. 1998;66(10):1395-1398.

131. Akamatsu N, Sugawara Y, Tamura S, Matsui Y, Kaneko J, Makuuchi M. Efficacy of mycofenolate mofetil for steroid-resistant acute rejection after living donor liver transplantation. World $J$ Gastroenterol. 2006;12(30):4870-4872.

132. Pfitzmann R, Klupp J, Langrehr JM, et al. Mycophenolatemofetil for immunosuppression after liver transplantation: a follow-up study of 191 patients. Transplantation. 2003;76(1):130-136.

133. Wiesner RH, Shorr JS, Steffen BJ, Chu AH, Gordon RD, Lake JR. Mycophenolate mofetil combination therapy improves long-term outcomes after liver transplantation in patients with and without hepatitis C. Liver Transpl. 2005;11(7):750-759. 
134. Jain A, Kashyap R, Demetris AJ, Eghstesad B, Pokharna R, Fung JJ. A prospective randomized trial of mycophenolate mofetil in liver transplant recipients with hepatitis C. Liver Transpl. 2002;8(1): 40-46.

135. Ciancio G, Miller J, Garcia-Morales RO, et al. Six-year clinical effect of donor bone marrow infusions in renal transplant patients. Transplantation. 2001;71(7):827-835.

136. Kawai T, Cosimi AB, Spitzer TR, et al. HLA-mismatched renal transplantation without maintenance immunosuppression. $N$ Engl J Med. 2008;358(4):353-361.

137. Strober S, Benike C, Krishnaswamy S, Engleman EG, Grumet FC. Clinical transplantation tolerance twelve years after prospective withdrawal of immunosuppressive drugs: studies of chimerism and anti-donor reactivity. Transplantation. 2000;69(8):1549-1554.
138. Kirk AD. Induction immunosuppression. Transplantation. 2006;82(5): 593-602.

139. Larsen CP, Knechtle SJ, Adams A, Pearson T, Kirk AD. A new look at blockade of T-cell costimulation: a therapeutic strategy for long-term maintenance immunosuppression. Am J Transplant. 2006; 6(5 Pt 1):876-883.

140. Scandling JD, Busque S, Dejbakhsh-Jones S, et al. Tolerance and chimerism after renal and hematopoietic-cell transplantation. $N$ Engl J Med. 2008;358(4):362-368.

\section{Publish your work in this journal}

Hepatic Medicine: Evidence and Research is an international, peerreviewed, open access journal covering all aspects of adult and pediatric hepatology in the clinic and laboratory including the following topics: Pathology, pathophysiology of hepatic disease; Investigation and treatment of hepatic disease; Pharmacology of drugs used for the treatment of hepatic disease. Issues of patient safety and quality of care will also be considered. The manuscript management system is completely online and includes a very quick and fair peer-review system, which is all easy to use. Visit http://www.dovepress.com/ testimonials.php to read real quotes from published authors.

Submit your manuscript here: http://www.dovepress.com/hepatic-medicine-evidence-and-research-journal 